\title{
Assessment Orientations of State Primary EFL Teachers in Two Mediterranean Countries
}

DINA TSAgari ${ }^{1}$

$\approx$ Many researchers have highlighted the central role that assessment plays in second language (L2) classrooms and have expressed the need for research into classroom-based language assessment (CBLA), an area that is gradually coming into its own in the field of language testing and assessment (e.g., Hasselgreen, 2008; Leung, 2014; Hill \& McNamara, 2012; Turner, 2012). Motivated by the prominence of CBLA in recent discussions, the present study set out to investigate the CBLA practices, knowledge and skills of Greek and Cypriot primary school EFL teachers. The data was collected through teacher interviews and classroom-based tests. The results showed that teachers employ a summative orientation towards evaluating their students' performance and seem to have unclear ideas about the purposes and implementation of formative assessment, mainly due to lack of professional training in language assessment. The paper concludes with suggestions as to how EFL teachers' CBLA literacy can be enhanced.

Keywords: language testing and assessment, classroom-based language assessment, assessment literacy, interviews, classroom-based tests, teacher training 


\section{Usmeritve državnih osnovnošolskih učiteljev angleščine kot tujega jezika na področju preverjanja/ocenjevanja v dveh mediteranskih državah}

DiNA TSAgARI

$\propto$ Veliko raziskovalcev poudarja osrednjo vlogo, ki jo ima preverjanje/ ocenjevanje pri učencih drugega jezika (J 2), in potrebo po raziskovanju procesov jezikovnega preverjanja/ocenjevanja v razredu. Preverjanje/Ocenjevanje jezikov v razredni situaciji postopoma pridobiva na pomembnosti in postaja področje raziskovanja $\mathrm{v}$ sklopu preverjanja in ocenjevanja jezikov (npr. Hasselgreen, 2008; Leung, 2014; Hill \& McNamara, 2012; Turner, 2012). Zaradi pogostih razprav o pomembnosti preverjanja/ocenjevanja jezikov v razredu smo v raziskavi skušali ugotoviti, kako se to izvaja v praksi, koliko vedenja ter katere zmožnosti imajo grški in ciprski osnovnošolski učitelji angleščine kot tujega jezika na tem področju. Podatki so bili zbrani s pomočjo intervjujev učiteljev in testiranjem v razredih. Izsledki kažejo, da učitelji pri evalviranju dosežkov učencev uporabljajo sumativni pristop ter da nimajo jasne predstave o namenu in načinu izvajanja formativnega ocenjevanja - vzrok je predvsem v pomanjkljivem strokovnem spopolnjevanju na področju preverjanja/ocenjevanja jezikov. V sklepnem delu so podani predlogi, kako bi lahko pri učiteljih angleščine kot tujega jezika izboljšali pismenost na področju preverjanja/ocenjevanja jezikov v razredu.

Ključne besede: ocenjevanje in preverjanje znanja, preverjanje/ ocenjevanje jezikov v razredu, pismenost na področju preverjanja/ ocenjevanja znanja in zmožnosti, intervjuji, testiranje v razredu, spopolnjevanje učiteljev 


\section{Introduction}

Assessment constitutes an important aspect of teachers' daily practice in the broad field of English language teaching (ELT) programmes worldwide. Classroom-based language assessment (CBLA), in particular, plays a central role in language teaching and learning and requires considerable time, knowledge and skills to be successfully implemented (Cheng, Rogers, \& Wang, 2008; Leung, 2014). Given its importance, CBLA is not to be neglected or taken for granted. Its effectiveness should become the driving force for every teacher who seeks to maximise student performance, maintain and/or increase student interest. Teachers must therefore be alert to situations in which opportunities for assessment appear, and must prepare efficiently for their CBLA activities.

Although the field of language testing and assessment (LTA) has recognised the importance of CBLA, language teachers are very often found to be insufficiently prepared for their assessment tasks and lack basic CBLA knowledge (Fulcher, 2012; Gatullo, 2000; Hasselgreen, 2000; Hasselgreen et al., 2004; Tsagari, 2012; Tsagari \& Michaeloudes, 2012; Vogt \& Tsagari, 2014). Researchers call for further investigation into teachers' CBLA practices (Leung, 2014), as we still do not have a complete picture of the ways in which language teachers cope with assessment demands and whether they possess the required competencies to carry out effective assessments. Motivated by such calls, the current small-scale comparative study will attempt to delineate the CBLA landscape in two Mediterranean countries and investigate the status quo of teachers' CBLA literacy in the state primary school sector.

\section{Literature Review}

Leung (2014) stresses that assessment is an integral part of teaching that has received a lot of attention recently. He also points out that CBLA, in particular, has been a major focus in curricula and is part of teachers' daily life in many parts of the world (Davison \& Leung, 2009). However, CBLA is not an easy task. Cheng, Rogers and Wang (2008) emphasise that "the day-today assessment of student learning is unquestionably one of the teacher's most demanding, complex and important tasks" (Cheng, Rogers, \& Wang, 2008, p. 10). It is indeed the case that in many ELT programmes teachers undertake the task of designing and administering classroom tests themselves. They are also required to use various forms of continuous or formative assessment procedures and develop or adapt scoring schemes for their institution. Furthermore, in many contexts teachers are faced with external testing procedures, e.g., 
school-leaving examinations and international standardised tests. In Europe in particular, new developments in language teaching, as well as EU policies on language learning, require new competencies of teachers. For example, the European Language Portfolio (Morrow, 2004; Schneider \& Lenz, 2001) highlights self-assessment as a supplement to teacher assessment. Peer assessment has also been added to the pedagogical agenda of the innovative foreign language teacher (Tsagari \& Meletiadou, 2015). These developments call for new skills to be acquired by language teachers (see also Edelenbos \& Kubanek-German, 2004), as the more teachers understand the nature and requirements of their assessment tasks, especially classroom-based assessment, the better they will be able to make principled decisions that can lead to beneficial uses of assessment to support enhanced language learning. For these reasons, teachers need to acquire sufficient levels of "assessment literacy".

Stiggins (2001, p. 531) defines "assessment literacy" of language teachers as representing the standards of professional excellence that teachers need to attain in relation to assessment, such as the ability to critically evaluate, compile, design and monitor assessment procedures in order to enhance learners' language achievement and use grading and scoring procedures based on theoretical knowledge. Assessment literacy is considered an important aspect of professionalism of language teachers and has become the topic of many presentations and discussions (Hasselgreen, 2008; Kaftandjieva, 2008; Reckase, 2008; Rogier, 2010). Language teachers with a solid background in assessment are said to be well equipped to integrate assessment into instruction and use appropriate forms of teaching leading to enhanced learning (Coombe, Al-Mamly, \& Troudi, 2009; Inbar-Lourie, 2008; Malone, 2008; Stoynoff \& Chapelle, 2005; Taylor, 2009).

Progress towards creating a culture of teachers who are assessment literate has, however, been slow. In his discussion of the professionalisation of language testing in the $21^{\text {st }}$ century, Bachman (2000, pp. 19-20) points out that "the majority of practitioners who develop and use language tests, both in language classrooms and as part of applied linguistics research, still do so with little or no professional training". This view is shared by Alderson (2005, p. 4), who notes that "Tests made by teachers are often of poor quality, and the insight they could offer into achievement, progress, strengths and weaknesses is usually very limited indeed". Empirical research also characterises teachers' CBLA practices as largely incongruent with recommended best practice, e.g., teachers are depicted as heavy users of tests (Goslin, 1967; Gullickson, 1984) or as falling short in terms of representing the full range of students' language skills in their assessment instruments and methods (Bobda, 1993; Pavlou \& Ioannou-Georgiou, 
2005). Teacher-made tests often contain inadequate or unclear instructions and do not specify assessment criteria (Khalil, 2010). Teachers are not concerned with the validity and reliability of their assessments (Sook, 2003) and report assessment results only by means of numbers (Pavlou \& Ioannou-Georgiou, 2005). In addition, they use formats corresponding to those used by formal external examinations (Falvey \& Cheng, 2000; Rogers, 1991), they seldom reflect on what is being assessed, and they are unaware of the assessment work of their colleagues (Black \& Wiliam, 1998; Harlen \& Deakin-Crick, 2003).

Teacher assessment practices are also found to vary according to teachers' experience, their views on the role of assessment in the curriculum, their collegial expectations and their external reporting demands (Cheng, Rogers, $\& \mathrm{Hu}, 2004)$. Studies also reveal that the practical constraints of the educational context (e.g., large classes and heavy teacher workload) are likely to affect the assessment of students' language abilities (Sook, 2003). Other studies have identified the presence of tensions between administrative and educational purposes for the use of assessment instruments and state-mandated assessment policies, which seem to have a restrictive effect on CBLA practices (Arkoudis \& O’Loughlin, 2004; Davison, 2004; Rogers, 1991).

Even though teachers report little or no training in CBLA, they do in fact show a high degree of awareness in determining their LTA priorities (AlSaadat, 2004; Hasselgreen, Carlsen, \& Helness, 2004; Tsagari \& Vogt, forthcoming; Vogt \& Tsagari, 2014). However, LTA training programmes do not always adequately cater for the assessment needs of language teachers. Jin (2010) found that, even though there was adequate coverage of essential aspects of theory and practice of language testing in the courses offered to EFL teachers in China, student classroom practice and educational and psychological measurement received considerably less attention across the country (see also Csépes, 2013).

To conclude, the literature reports teachers' limited knowledge and training with regard to the standards required in order to practice successful CBLA procedures compatible with the teachers' teaching techniques or the needs of learners (Arkoudis \& O'Loughlin, 2004; Davison, 2004; Falvey \& Cheng, 2000; Ferman, 1998; Shohamy, 1998). However, studies conducted in the field of CBLA have mainly been carried out with teenage and adult learners, while assessing young learners has remained largely under-researched. Except for the seminal work of Penny McKay (2006), who built a comprehensive framework for the assessment of young language learners in both foreign language and second language learning situations, the number of CBLA studies with young learners (5-12 years old) has been very limited. Assessing young foreign language learners is a sensitive area and as such deserves special attention, as inappropriate 
assessment procedures may have lifelong negative consequences for students' attitudes and motivation regarding language learning (Nikolov, 2016). If educators are to support and enhance the CBLA literacy of primary school teachers, more must be learned about how teachers currently perceive and use CBLA and what their training needs are. The present study will therefore investigate the CBLA practices and training needs of language teachers of young learners in the primary sector of two educational contexts (Greece and Cyprus) where research in the field is limited. The results of the study are expected to help teachers, researchers and decision makers to understand and apply appropriate assessment procedures for young learners.

\section{Research Methodology}

\section{Research questions}

Motivated by the relevant literature and the need for research in the area of assessing young learners in the two contexts in question, the present study set out to explore the nature of the CBLA practices of EFL teachers working in the primary sector. The following research questions guided the study:

- Which CBLA practices do Greek and Cypriot EFL primary school teachers employ with their young learners?

- What level of training in CBLA do the EFL teachers have?

- To what extent do the teachers perceive a need for further in-service training in CBLA?

Parallels will be drawn between what the literature proposes in the field of language assessment and the data collected with respect to current teachers' CBLA literacy. Moreover, since this study was conducted in two educational contexts, comparisons will be made between the two groups involved.

\section{Research Design}

The current study followed a mixed-methods approach (Creswell, 2015; Teddlie \& Tashakkori, 2009) to data collection that aimed at triangulating data from different sources in order to enhance the validity of the study (Turner, 2014). Interviews focusing on CBLA assessment practices constituted a basic tool for the collection of data from teachers (see also Cheng \& Wang, 2007; Pelly \& Allison, 2000). Cohen, Manion and Morrison (2007) note that interviews allow for great depth in comparison to other methods of data collection. 
The interview questionnaire prepared for use in the present study was mainly exploratory; it consisted of open-ended questions that sought to determine teachers' assessment practices and procedures (see Appendix A). The reliability of the interview questions was attained by pre-testing the questionnaire (Silverman, 1993) with a small sample of English teachers.

The interview questions were divided into three sections. The first part of the questionnaire (Bio Section) was used to gain an overall idea of the teachers' instructional background. In the second section (Assessment Procedures), teachers were asked to provide information about their assessment practices in terms of types and frequency of tests, use of other forms of assessment, etc. The third part of the questionnaire (Training in Assessment) contained questions about teacher training: it identified characteristics of pre- and in-service training and the extent to which teachers felt appropriately prepared for their CBLA tasks.

Once the relevant permissions were obtained in both countries to carry out the research study, teachers were contacted and informed of its purposes and were invited to participate on a voluntary basis. The interviews were conducted at venues and times that were convenient for the teachers. Each interview lasted approximately 45 minutes. At the end of the data collection period, all of the teachers' answers were processed and coded. The interview responses were initially sorted according to the predetermined questions. The data analysis involved a number of readings of the data entries and a progressive refining of the categories of analysis.

At the end of each interview, sample tests were collected from the teachers. These were analysed in terms of the types of language skills assessed and in terms of frequencies and percentages (see Table 1 ).

For the interpretation of the data, the study employed a sociocultural theory perspective that has recently had a significant impact on the analysis and interpretation of classroom experiences and the development of learning skills (Kramsch, 2002; Lantolf, 2000; Lantolf \& Thorne, 2006; Swain, Kinnear, \& Steinman, 2011). In line with this way of thinking, the data were related to the sociocultural reality of the two contexts under study and reflected upon through the realities of the local education system, society and culture in which they occurred.

\section{Context and participants}

English as a Foreign Language (EFL) is taught from grade one in state primary schools in Greece and Cyprus. The weekly contact hours allocated 
for tuition vary between two and three, depending on local regulations. Classrooms can accommodate a maximum of 25 students, depending on the school resources. The state sector overall is responsible for implementing the country's obligations stemming from EU policies concerning language teaching and assessment, as stipulated in the English Language Curricula in both countries. ${ }^{23}$ The latter are based on CEFR levels (Council of Europe, 2001) and follow good practice in assessment, e.g., by suggesting formative and summative orientations in CBLA.

In the present study, four Greek and four Cypriot EFL state primary school teachers agreed to take part in the study (eight teachers in total). The selection of teachers was based on a random sample, as the current study did not target any particular general characteristics, e.g., the age or gender of the teachers. The teachers taught fifth- and sixth-grade school students (10-11 and 11-12 years, respectively) and met the basic requirements for employment in the primary sector in each country, e.g., the teachers in Cyprus had a bachelor degree in Education, while the teachers in Greece had a degree in English Language and Literature. Four of the teachers (one from Greece and three from Cyprus) also had an MA degree (Teaching English, Applied Linguistics or Educational Leadership). The teachers' level of experience ranged from 4 to 16 years.

The next section presents the results of the study where teachers' CBLA practices are illustrated via extracts from the interviews. In order to safeguard the identities of the participants, code names will appear next to the extracts identified, first by country - CY (Cyprus) or GR (Greece) - and then by a code name to denote the different teachers, e.g. $\mathrm{T}_{1}, \mathrm{~T}_{2}$, etc.

\section{Findings}

\section{Testing practices}

In response to the first question regarding whether the teachers tested their students, the interviewees explained that, even though they were not obliged to do so, they usually tested their students through paper-and-pencil tests. The teachers were asked how often and why they use tests to assess their students' performance. The answers indicated that the majority of the teachers (six of the eight) usually test their students every 3-4 units, while two of the

2 (Greece) Pedagogical Institute (2003) Cross-Thematic Curriculum Framework for Compulsory Education DEPPS (official English translation of part of the text available). Retrieved on 15.09.2015, from http://www.pi-schools.gr/download/programs/depps/english/14th.pdf

3 (Cyprus) Pedagogical Institute (2012) The English Curriculum (in Greek). Retrieved on 15.09.2015, from http://www.schools.ac.cy/klimakio/Themata/Anglika/curricula.html 
teachers (GRT3, GRT4) test their students as soon as they finish each unit. This helps them to find out about the students' progress, to reflect on their instruction - e.g. "that tells me how to plan the next unit" (CYT1) - and to identify possible problems students face, which can subsequently be addressed through remedial work.

When designing their tests, Cypriot teachers explained that they primarily focus on two criteria: average students and, to a certain extent, Ministry standards.

"Of course, average students. The test needs to address average students, but my tests have tasks of different levels of difficulty" (CYT4).

On the other hand, in designing their tests, Greek teachers consider the level of the class and the individual student, as well as the areas they have taught.

In terms of content, the results from the analysis of a sample of teachermade tests (see Table 1) show a strong preference for the assessment of vocabulary and grammar, followed by writing, while testing of reading and listening skills was infrequent. Speaking tasks were rarely encountered in the tests, and were completely absent in the case of the Cypriot sample.

Table 1. Results of test analysis

\begin{tabular}{lcccc}
\hline \multirow{2}{*}{ Skills/Elements } & \multicolumn{2}{c}{ Greece } & \multicolumn{2}{c}{ Cyprus } \\
& (N=192 activities, 35 tests) & (N=106 activities, 19 tests) \\
\cline { 2 - 5 } Rrequency & Percentage & Frequency & Percentage \\
Writing & 8 & 4.1 & 6 & 5.7 \\
Listening & 25 & 13.0 & 14 & 13.2 \\
Speaking & 6 & 3.1 & 4 & 3.8 \\
Grammar & 4 & 2.1 & - & - \\
Vocabulary & 70 & 36.5 & 18 & 17.7 \\
\hline
\end{tabular}

Further analysis of the tests showed that the most popular task type for the assessment of vocabulary was sentence and word completion. Other tasks were: matching, crossword puzzles, true or false, correct sentences, odd word out, answer questions and finding the correct order. Regarding the assessment of grammar, two types of tasks were used more frequently: sentence completion and answering questions. In general, the tests analysed followed more or less the same pattern in both contexts. 


\section{Marking of tests}

With regard to the marking of tests, five of the teachers (GRT2, GRT4, $\mathrm{CYT}_{1}, \mathrm{CYT}_{3}, \mathrm{CYT}_{4}$ ) reported that they were not strict with the correction of tests. One of the teachers noted "I'm strict on the things I have taught and the objectives of the test tasks" (CYT2). The format of the tests also seems to play an important role in the way teachers mark tests. As GRT3 explained, she is strict if it is a multiple choice test, but if it is an open-ended task she tends to be lenient.

\section{Test usefulness}

The questionnaire responses also showed that the teachers had similar opinions with regard to the usefulness of their test results. For instance, the majority of the Cypriot teachers (CYT1, CYT2 and $\mathrm{CYT}_{4}$ ) believe that classroom tests are an indication of what students can do, and that such texts demonstrate whether or not students have studied. However, CYT2 thinks otherwise: "there's always the possibility that test results are not indicative of what the student knows".

Greek teachers also shared this belief: for them, test results provide diagnostic information, e.g., they indicate the problems students face and the learning areas teachers need to emphasise instructionally. As GRT2 stressed, tests "tell me almost everything. They clearly show each student's progress".

Teachers were also asked to comment on the extent to which the criteria they use are clear to students. All of the teachers except GRT4 stressed that students know exactly what needs to be done and that their assessment criteria are clear, e.g., "my students know what the test exercises ask from them and the way I mark" (CYT4).

In response to the question as to whether teachers take classroom tests into account or whether they include test results in student reports, the teachers shared the same opinions. Six of the teachers take test results into account, while two (GRT2, GRT4) do not. GRT4 justified her choice as follows: "No, I don't. Otherwise their marks would be basically very low for most of them". Thus, $\mathrm{GRT}_{4}$ takes into consideration the psychological parameters that are likely to affect her students.

\section{Feedback provided to students}

Teachers provide certain types of feedback to students once the tests are marked. For example, the majority of teachers report test results in class while the test papers are handed back to the students and highlight the mistakes students have made and the areas they identify as problematic, e.g.,

"I show them the tests and then we have a discussion about how to avoid making the same mistakes" (GRT1) 
It is also worth mentioning that, in addition to answering students' questions, teachers try to do remedial work to help students overcome their language problems. One of the teachers $\left(\mathrm{CYT}_{3}\right)$, however, does not do remedial work with her students but instead comments positively on the test results. This teacher added:

"If I see that there is some kind of difficulty, I will indicate that on the student's test paper" (CYT3)

\section{Students' reactions to tests}

When asked about students' reaction to tests, teachers believed that in general students like tests and look forward to them (GRT1, GRT2). They also said that students find tests easy but treat them seriously (GRT3, CYT2) and have a positive attitude towards them (CYT1, CYT3, CYT4). Some teachers pointed that, given the age of the students, tests should also include game-like tasks $\left(\mathrm{CYT}_{3}\right)$.

\section{Standardised tests}

In response to the question as to whether teachers had ever worked with standardised tests (e.g., Cambridge Preliminary English Test, Key English Test or English Young Learners, etc.) or whether they had advised learners in this area, the majority of the teachers said that they had never done so. This is because there is no requirement to prepare students for such tests in the public sector. Even if there was such a requirement, teachers reported that they are not qualified or trained to assist students in their preparation for external tests.

\section{Other types of assessment}

In response to the question as to whether teachers used alternative approaches in their assessment repertoire - e.g., portfolio assessment, self- or peer-assessment - the analysis showed that, despite being aware of these methods, teachers were still far from implementing them appropriately or efficiently with young learners. Teachers did show some awareness of alternative forms of assessment. GRT2, for example, said that she used games and various other playful activities, while GRT3 reported that she used self- and peer- assessment as well as group work in order to assess her students. However, neither of these two teachers could explain exactly how they did so, which was true of the majority of the Cypriot teachers who acknowledged the use of alternative methods of assessment, e.g.:

"If I want to assess vocabulary, I will have a Bingo activity where, through the use of dice, students will ask and answer or find things out. Through 
this, for instance, I can check their vocabulary" (CYT3).

CYT2 also referred to the use of projects for assessment purposes, e.g.:

"We usually have some mini-scale projects. For instance, we worked with a short story, 'The Three Little Pigs', and I prepared a small project for them, which I then use as a form of evaluation".

CYT2 also used plays performed during the lesson as a way to assess student performance:

"Some units are ideal for using 'theatre plays' because they are very indicative of what they know. They are more natural, more spontaneous, and as a result you can understand their level and progress".

With regard to portfolio assessment, only $\mathrm{CYT}_{4}$ said that she had partly used portfolios, while CYT2 was planning to implement portfolios the following year. CYT1 stated that she "checks on students through singing activities", while $\mathrm{CYT}_{2}$ and $\mathrm{CYT}_{3}$ stressed that they used either pair or group work as a means of assessment.

\section{The usefulness of alternative forms of assessment}

Teachers' responses were divided with regard to the usefulness of alternative methods of assessment. For instance, Cypriot teachers believe that alternative methods are actually better than tests, e.g., "of course these are better ways because they are more indicative of what students can do" (CYT4), whereas Greek teachers believe that they are equally useful to tests (GRT2, GRT3), e.g., "I think they are equally useful and I wish I had more time to discuss them with the students" (GRT1).

While the majority of the teachers said that they use alternative forms of assessment to make their teaching more effective and adjust to the students' needs, two teachers $\left(\mathrm{GRT}_{3}, \mathrm{CYT}_{3}\right)$ reported that such forms of assessment help students to overcome certain difficulties. Teachers are not, however, interested in the results of such methods (e.g., GRT1, CYT2), explaining that they simply keep a record of the results of alternative assessments (e.g., they note the results in their notebooks). Overall, teachers find alternative forms of assessment very helpful because these methods are believed to enhance both their teaching methods and student learning, e.g., "I take them into account and try to adjust my teaching to my students' needs (GRT2)”. 


\section{Other factors teachers consider when evaluating students}

Teachers were asked about any other factors they consider when they evaluate their students. The results revealed a difference between the two groups. Greek teachers appear to take into consideration the personality of their students in their evaluations during lessons, as well as the students' participation and effort throughout the year:

"I pay attention to the student himself, to his or her effort, willingness and behaviour." (GRT2)

Cypriot teachers, on the other hand, concentrate on students' overall performance and willingness to learn, their first language (L1) and their family background. CYT2 and $\mathrm{CYT}_{3}$ explained that students with an $\mathrm{L}_{1}$ other than Greek face a number of problems, and that this is crucial when evaluating these students. Finally, CYT1 pays attention to family problems or even learning difficulties such as dyslexia and other language difficulties.

\section{Teacher training in CBLA}

Concerning professional seminars and training, Cypriot teachers (CYT1, CYT2, and CYT4), unlike their Greek colleagues, reported attendance of several seminars organised by the Pedagogical Institute, which they found helpful and practical. The teachers were also asked whether they had learned anything about language testing and assessment during their pre-service teacher training. Even though preparation for assessment is important to the respondents, they stressed that training in language assessment had been neglected during their undergraduate studies and pre-service training, e.g.:

“.... definitely not. We didn't receive any such information” (CYT4)

"I do not feel prepared... There's no preparation in such matters for the primary school English teacher" (CYT2)

The general feeling of the teachers was that work needs to be done in language assessment because teachers lack the appropriate knowledge and they need to improve their overall competence in CBLA. Teachers were also asked about the type of CBLA training they would like to receive. One of the teachers commented:

"I believe that there should be better professional training and orientation in language assessment because, although we may actually use some individual and group assessment, this is not enough..." (CYT3) 


\section{Summary of the results and discussion}

The present study highlights the centrality of CBLA in EFL teaching and learning by exploring teachers' CBLA practices for assessing their young EFL students' language skills. The study also evaluates the quality of teacher training in this area as part of the teachers' professional agenda.

As the data showed, despite minor differences, both groups of teachers use tests as their basic CBLA method with varying frequency, as this helps them to gauge the progress of their students' learning and to assess the effectiveness of their teaching. Nevertheless, the analysis showed that, in terms of content, teacher-made tests include a limited range of language skills, usually restricted to the assessment of vocabulary and grammar. There is also lack of creativity with regard to the task types. Furthermore, the criteria teachers use to select testing materials or provide feedback on test results is inconsistent. Feedback procedures in particular seem to reflect a deficit-oriented approach rather than the more positively worded feedback that is inherent in the Common European Framework of Reference and its descriptors, which value competencies even on low levels rather than highlight deficits (Vogt, 2004). If frequently employed, such practices will probably be of no particular benefit to teachers and students in the long run, and are likely to result in processes that are not conducive to learning the language (referred to as the 'washback effect', see Alderson \& Wall, 1993).

Irrespective of the students' positive reaction, the teachers expressed their doubts regarding the use of tests as a means of assessment. They seem to be aware that testing procedures can help them to plan their lessons or identify students' problematic areas, but they are also aware of the need to adopt methods that appeal to young learners. The teachers were sensitive towards their students age with regard to marking, and they take into account psychological factors that might affect students' learning. The results also showed that alternative forms of assessment have not yet fully entered mainstream assessment practices in primary schools in both countries. Concepts related to alternative assessment methods remain fuzzy to the respondents in the study, which is attributable to low language assessment literacy levels. Consequently, teachers have difficulties specifying their personal professional development needs in CBLA, despite their desire to receive training in this area.

Summarising the findings from the interviews, one can see that the respondents in our study tend to revert to traditional assessment procedures that are essentially written, and typically use similar assessment formats. The results indicate that teachers of young EFL learners experience various roles; for example, as well as being teachers, they are 'supporters of language development' and 
they also play the role of 'examiners' and 'raters'. In these roles, teachers place an emphasis mainly on 'what' students are able to achieve rather than 'how' they can be supported in their language learning. As a result, teachers fail to grasp the potential for the implementation of formative assessment with their students. This is mainly due to a lack of teacher training. Language assessment in the educational contexts examined is therefore reduced to assessment of learning (summative assessment) rather than assessment for learning (formative assessment). As noted by Rea-Dickins (2007), this approach is likely to lead teachers to an orientation towards 'language display' rather than 'language development opportunities'.

The evidence also showed that the teacher education programmes offered to EFL teachers of young learners do not provide adequate training in CBLA. In their answers, teachers stressed that they do not consider themselves to be competent or literate in CBLA; they were aware of more recent forms of assessment, such as portfolio, peer- or self-assessment, but were far from being able to efficiently implement them due to a lack of professional training.

These findings are troubling given that the international research literature proposes a synergy between the different types of assessment for improving student learning and achievement in schools (Black \& Wiliam, 1998). The data gathered does, however, provide some promising signs that EFL teachers are thinking seriously about their place within CBLA and are ready for greater levels of involvement in training initiatives in order to broaden and diversify their assessment literacy, with varying priorities depending on contextual assessment requirements. The teachers repeatedly pointed out that their assessment competency had not yet reached a level that would allow them to feel sufficiently confident about their CBLA activities; rather, they realise that professional training is required, and that this aspect of their teaching is one that definitely needs improvement. What will benefit teachers is professional development in this area.

Attending to teachers' professional knowledge and practice in CBLA will contribute to the development of a dynamic and contextually sensitive assessment literacy culture in EFL education of young learners. The challenge undoubtedly lies in providing appropriate and available professional development opportunities for teachers to meet their assessment needs. An assessment literacy development strategy could, for example, rely on a combination of training programmes in varying proportions: formal CBLA courses (BA and MA level) and pre- and in-service CBLA workshops (of appropriate length and quality) will expose teachers to new ideas and help them to meet their professional assessment needs and responsibilities. However, such courses and workshops also 
need to capitalise on teachers' existing experience and practices, and take into account the results of assessment needs analysis, such as those reported in the present study. Training programmes also need to recognise and deal with the reality and constraints influencing teachers' assessment practices and encourage an action-research approach to professional development that combines theory with practice in the classroom. Training courses should also involve policy, decision makers and teachers in collaborative assessment development projects (Stiggins, 1999a, b) and allow students to be involved in assessment in order to build their confidence and maximise their achievement (Stiggins, 2001). Otherwise, such training endeavours might fall short of the professional development standards of EFL teachers (see also Harding \& Kremmel, 2016; Taylor, 2009).

\section{Concluding remarks}

Assessing young foreign language learners is a sensitive and complex area (Nikolov, 2016). Despite its small scale, the present comparative study was carried out in a thorough way and reveals urgent discussion points. For example, it clearly shows that the implementation of the CEFR for assessment purposes - in particular assessment for learning, which is one of the most important issues for early language learning today - is very slow in classrooms in Europe. It seems that language learning still relies on summative testing of vocabulary, grammar and writing in the so-called communicative language classroom. Given that other school subjects have already successfully embraced formative assessment (Bell \& Cowie, 2001; Ruiz-Primo et al., 2015; Scott et al., 2006; Shavelson et al., 2008), we urgently need to implement assessment for learning for the sake of our young language learners. Future research studies can investigate the effectiveness of such assessment procedures and explore the extent to which they can contribute to the quality lifelong development of the language competence of children.

\section{References}

Alderson, J. C. (2005). Diagnosing Foreign Language Proficiency. London / New York: Continuum. Alderson, J. C., \& Wall, D. (1993). Does washback exist? Applied Linguistics, 14(2), 115-129. Al-Saadat, A. I. (2004). A Close Look at Saudi EFL Teachers Preparation in Language Testing. Scientific Journal of King Faisal University, 5(2), 227-254. Retrieved from http://www.223kfu.edu.sa/ sjournal/eng/pdfiles/A527.pdf

Arkoudis, S., \& O’Loughlin, K. (2004). Tensions between validity and outcomes: teacher assessment of written work of recently arrived immigrant ESL students. Language Testing, 21(3), 284-304. 
Bachman, L. F. (2000). Modern language testing at the turn of the century: Assuming that what we count counts. Language Testing, 17(1), 1-42.

Bell, B., \& Cowie, B. (2001). Formative assessment and science education. Dordrecht, The Netherlands: Kluwer.

Black, P., \& Wiliam, D. (1998). Assessment and Classroom Learning. Assessment in Education: principles, policy and practice, 5(1), 7-74.

Bobda, A. S. (1993). Testing Pronunciation. English Teaching Forum, 31(3). Retrieved from http:// exchanges.state.gov/englishteaching/forum/archives/1993/docs/1993-1931-1993-e.pdf

Cheng, L., \& Wang, X. (2007). Grading, Feedback, and Reporting in ESL/EFL Classrooms. Language Assessment Quarterly, 4(1), 85-107.

Cheng, L., Rogers, T., \& Hu, H. (2004). ESL/EFL instructors' Classroom Assessment Practices:

Purposes, Methods, and Procedures. Language Testing, 21(3), 360-389.

Cheng, L., Rogers, T. W., \& Wang, X. (2008). Assessment purposes and procedures in ESL/ EFL classrooms. Assessment and Evaluation in Higher Education, 33(1), 9-32.

Cohen, L., Manion, L., \& Morrison, K. (2007). Research Methods in Education, $6^{\text {th }}$ edition. London: Routledge.

Coombe, C., Al-Mamly, M., \& Troudi, S. (2009). Foreign and second language teacher assessment literacy: Issues, challenges and recommendations. Research Notes, 38, 14-18.

Council of Europe. (2001). Common European Framework of Reference for Languages: Learning, teaching, assessment. Cambridge: Cambridge University Press.

Creswell, J. W. (2015). A Concise Introduction to Mixed Methods Research. Los Angeles, CA: Sage. Csépes, I. (2013) Language Assessment Literacy (LAL) in the Hungarian context: what is it like and how is it developed in English teacher training? Paper presented at the $4^{\text {th }}$ CBLA SIG Symposium. Nicosia, Cyprus, 1 to 2 November 2013.

Davison, C. (2004). The contradictory culture of teacher-based assessment: ESL teacher assessment practices in Australian and Hong Kong secondary schools. Language Testing, 21(3), 305-334.

Davison, C., \& Leung, C. (2009). Current issues in English language teacher-based assess-ment. TESOL Quarterly, 43(3), 393-415.

Edelenbos, P., \& Kubanek-German, A. (2004). Teacher Assessment: The Concept of Diagnostic Competence. Language Testing, 21(3), 259-283.

Falvey, P., \& Cheng, L. (2000). Paradigm shift: Teachers' classroom assessment practices in Hong Kong and the PRC. Melbourne Papers in Language Testing, 9(1), 29-50.

Ferman, I. (1998). The impact of a new English foreign language oral matriculation test on the educational system. Unpublished MA thesis. Israel: Tel Aviv University.

Fulcher, G. (2012). Assessment Literacy for the Language Classroom. Language Assessment Quarterly, $9(2), 113-132$.

Gattullo, F. (2000). Formative assessment in ELT primary (elementary) classrooms: an Italian case study. Language Testing 17(2), 278-288.

Goslin, D. A. (1967). Teachers and Testing ( $2^{\text {nd }}$ ed.). New York: Russell Sage Foundation. 
Gullickson, A. R. (1984). Teacher Perspectives of Their Instructional Use of Tests. Journal of Educational Research, 77, 244-248.

Harding, L., \& Kremmel, B. (2016). Teacher assessment literacy and professional development. In D. Tsagari \& J. Banerjee (Eds.), Handbook of Second Language Assesmsent (pp. 413-427). Berlin \& N. York: Muton De Gruyter.

Harlen, W., \& Deakin-Crick, R. (2003). Testing and Motivation for learning. Assessment in Education: principles, policy \& practice, 10(2), 169-207.

Hasselgreen, A. (2008). Literacy in Classroom Assessment (CA): What Does This Involve? Paper presented at the $5^{\text {th }}$ Annual Conference of EALTA. Athens, Greece. Retrieved 24.03.2013 from http:// www.ealta.eu.org/conference/2008/docs/sunday/panel/Literacy\%2oin\%2oclassroom\%2oassessment. pdf

Hasselgreen, A. (2000). The assessment of the English ability of young learners in Norwegian schools: an innovative approach. Language Testing, 17(2), 261-277.

Hasselgreen, A., Carlsen, C., \& Helness, H. (2004). European Survey of Language Testing and Assessment Needs. Part One: General Findings. Retrieved 23.03.2013 from www.ealta.eu.org/resources Hill, K., \& McNamara, T. (2012) Developing a comprehensive, empirically based research framework for classroom-based assessment. Language Testing, 29(3), 395-420

Inbar-Lourie, O. (2008). Constructing a language assessment knowledge base: A focus on language assessment courses. Language Testing, 25(3), 385-402.

Jin, Y. (2010). The place of language testing and assessment in the professional preparation of foreign language teachers in China. Language Testing, 27(4), 555-584.

Kaftandjieva, F. (2008). Assessment Literacy in Europe and Beyond: Realities and Prospects. Paper presented at the $5^{\text {th }}$ Annual Conference of EALTA. Athens, Greece. Retrieved from http://www.ealta. eu.org/conference/2008/docs/sunday/panel/Panel.pdf

Khalil, A. (2010). A Study of EFL Teachers' Assessment Practices. In D. Koksal, I. H. Erten, E. Zehir Topkaya, \& A. Yavuz (Eds.), The $6^{\text {th }}$ International ELT Research Conference. Conference Proceedings: Current Trends in SLA Research and Language Teaching (pp. 71-75). Selçuk, İzmir, Turkey.

Kramsch, C. J. (Ed.) (2002). Language acquisition and language socialization: ecological perspectives. London, New York: Continuum.

Lantolf, J. P. (Ed.) (2000). Sociocultural Theory and Second Language Learning. Oxford: Oxford University Press.

Lantolf, J. P., \& Thorne, S. L. (2006). Sociocultural Theory and the Genesis of Second Language Development. Oxford: Oxford University Press.

Leung, C. (2014). Classroom-based Assessment Issues for Language Teacher Education. In A. J. Kunnan (Ed.), The Companion to Language Assessment (pp. 1510-1519). John Wiley \& Sons, Inc. Malone, M. (2008). Training in language assessment. In E. Shohamy \& N. Hornberger (Eds.), Encyclopedia of language and education. Language testing and assessment ( $2^{\text {nd }}$ ed., Vol. 7) (pp. 225239). New York: Springer Science and Business Media.

McKay, P. (2006). Assessing Young Second and Foreign Language Learners. Cambridge: Cambridge 
University Press.

Morrow, K. (2004). Insights from the Common European Framework. Cambridge: Cambridge University Press.

Nikolov, M. (Ed.) (2016). Assessing Young Learners of English: Global and Local Perspectives. New

York: Springer.

Pavlou, P., \& Ioannou-Georgiou, S. (2005). The use of tests and other assessment methods in Cyprus State Primary School EFL. In P. Pavlou \& K. Smith (Eds.), Serving TEA to Young Learners: Proceedings of the Conference on Testing Young Learners (pp. 54-72). University of Cyprus: IATEFL and CyTEA, Israel: ORANIM - Academic College of Education.

Pelly, C. P., \& Allison, D. (200o). Investigating the views of teachers on assessment of English language learning in the Singapore education system. Hong Kong Journal of Applied Linguistics, 5(1), 81-106.

Rea-Dickins, P. (2007). Classroom-based assessment: Possibilities and pitfalls. In J. Cummins \& C.

Davison (Eds.), The International Handbook of English Language Teaching. Vol. 1 (pp. 505-520). New

York: Springer.

Reckase, M. (2008). Assessment Literacy. Paper presented at the $5^{\text {th }}$ Annual Conference of EALTA.

Athens, Greece. Retrieved from http://www.ealta.eu.org/conference/20o8/docs/sunday/panel/

Reckase.pdf

Rogers, T. (1991). Educational assessment in Canada: evolution or extinction? The Alberta Journal of Educational Research, 37, 179-192.

Rogier, D. (2010). Assessment Practices and Beliefs: Strengthening Assessment Literacy of EFL Teachers. Paper presented at the the $44^{\text {th }}$ Annual International IATEFL Conference and Exhibition. Harrogate, UK.

Ruiz-Primo, M. A., Kroog, H. I., \& Sands, D. I. (2015). Teachers' Judgments On-The-Fly: Teachers' Response Patterns in the Context of Informal Formative Assessment. $16^{\text {th }}$ Biennial Conference EARLI (European Association for Research in Learning and Instruction), Cyprus University of Technology (CUT), Limassol, Cyprus, 25-29 August 2015.

Schneider, G., \& Lenz, P. (2001). European language portfolio: Guide for developers. Strasbourg: Council of Europe.

Scott, P. H., Mortimer, E. F., \& Aguiar, O. G. (2006). The tension between authoritative and dialogic discourse: A fundamental characteristic of meaning making interactions in high school science lessons. Cognition and Instruction, 20, 399-484.

Shavelson, R. J., Yin, Y., Furtak, E. M., Ruiz-Primo, M. A., \& Ayala, C. (2008). On the role and impact of formative assessment on science inquiry teaching and learning. In J. Coffey, R. Douglas, \& C. Stearns (Eds.), Assessing science learning. Perspectives from research and practice (pp. 21-36). Arlington, VA: National Science Teachers Association Press.

Shohamy, E. (1998). Inside the 'black box' of classroom language tests. Studia Anglica Posnaniensia, XXXIII, 343-352.

Silverman, D. (1993). Interpreting qualitative data: Methods for analyzing talk, text and interaction. 
London: Sage Publications.

Sook, K. H. (2003). Korean junior secondary school English teachers' perceptions of speaking assessment. Asian EFL Journal, 5(4), 1-30. Retrieved from http://www.asian-efl-journal.com/dec_03_ gl_kr.php

Stiggins, R. J. (1999a). Learning teams can help educators develop their collective assessment literacy. Journal of Staff Development, 20(3) [online]. Retrieved 28.09.2011 from http://www.nsdc.org/library/ publications/jsd/stiggins203.cfm

Stiggins, R. J. (1999b). Teams. Journal of Staff Development, 20(3) [online]. Retrieved 28.09.2011 from http://www.nsdc.org/library/publications/jsd/stiggins203.cfm

Stiggins, R. J. (2001). Student-Involved Classroom Assessment ( ${ }^{\text {rd }}$ ed.). Upper Saddle River, NJ:

Prentice-Hall, Inc.

Stoynoff, S., \& Chapelle, C. (2005). ESOL tests and testing: A resource for teachers and program administrators. Alexandria, VA: TESOL.

Swain, M., Kinnear, P., \& Steinman, L. (2011). Sociocultural Theory in Second Language Education: An Introduction through Narratives. Bristol: Multilingual Matters.

Taylor, L. (2009). Developing Assessment Literacy. Annual Review of Applied Linguistics, 29, 21-36.

Teddlie, C., \& Tashakkori, A. (2009). Foundations of Mixed Methods Research: Integrating

Quantitative and Qualitative Approaches in the Social and Behavioral Sciences. Los Angeles, CA: Sage.

Tsagari, D. (2012). Classroom evaluation in EFL state-schools in Greece and Cyprus: towards 'assessment literacy'. Journal of Applied Linguistics (Annual Publication of the Greek Applied Linguistics Association), 27, 127-149.

Tsagari, D., \& Meletiadou, E. (2015). 'Peer assessment of adolescent learners' writing performance'. Writing \& Pedagogy, 7(2), 305-328.

Tsagari, D., \& Michaeloudes, G. (2012). 'Formative assessment practices in private language schools in Cyprus. In D. Tsagari (Ed.), Research on English as a Foreign Language in Cyprus (Vol. II) (pp. 246265). Nicosia: University of Nicosia Press.

Tsagari, D., \& Vogt, K. (forthcoming). Assessment Literacy of Foreign Language Teachers around Europe: Research, Challenges and Future Prospects. In K. Hill \& C. Davison (Eds.), Teacher Assessment Literacy in Second and Foreign Language Education. Educational Linguistics: Springer. Turner, C. E. (2012). Classroom Assessment. In G. Fulcher \& F. Davidson (Eds.), The Routledge Handbook of Language Testing (pp. 65-78). London and New York: Routledge.

Turner, C. E. (2014). Mixed Methods Research. In A. J. Kunnan (Ed.), The Companion to Language Assessment (pp. 1403-1417). John Wiley \& Sons, Inc.

Vogt, K. (2004). Der Gemeinsame Europäische Referenzrahmen für Sprachen: Inhalte, Ziele, Diskussion. [The Common European Framework of Reference for Languages: Contents, Aims, Discussion.]. Der Fremdsprachliche Unterricht Englisch, 38(69), 48-51.

Vogt, K., \& Tsagari, D. (2014). Assessment literacy of foreign language teachers: Findings of a European study. Language Assessment Quarterly, 11(4), 374-402. 


\section{Biographical note}

Dina Tsagari is Assistant Professor in Applied Linguistics/TEFL at the Department of English Studies, University of Cyprus. Her main research interests are language testing and assessment, teacher training, materials design, and evaluation. She has taught and conducted research in Hong Kong, Cyprus, Greece, and other European countries. Dina is the editor and author of several volumes, journal papers, and book chapters. She is also the coordinator of the Classroom-based Language Assessment SIG - EALTA and currently principal investigator in a research project on second language assessment literacy. 


\title{
Appendix A
}

\section{QUESTIONNAIRE FOR ENGLISH TEACHERS}

\author{
Section I - Bio Section
}

1. Male $\square \quad$ Female

2. Teaching qualifications

3. English teaching qualifications

4. Years of teaching experience

5. Type of professional training/seminars esp. for teaching English

\section{Section II - Assessment Procedures}

6. How do you assess your students' performance?

7. Do you use tests? If so, how often do you use them? Why?

8. Do you have to use tests or are you given other options?

9. What do you take into account when you design these tests? The best students? Average students? Weak students? Other?

10. What do the results of these tests tell you about your students?

11. Do you take the results into account? Do you include these results in the reports of each student?

12. How strict are you with the correction of these tests?

13. Do you believe in test results?

14. What do your students say about the tests they take? What is their attitude towards them?

15. Are the criteria you use to mark tests clear to your students?

16. How do you usually report back on a test taken by your students?

17. Do you, or have you ever, prepared students for international exams (e.g., PET, KET, CAMBRIDGE YOUNG LEARNERS exams or other)? If so, how do you like this experience?

18. What other forms of assessment do you use to measure your students' progress?

19. Do you find these equally useful to tests, better or worse?

20. What do you do with the results of these assessments?

21. What would you use as a way of assessing your students if you were able to choose your own assessment methods?

22. What other factors do you consider when you evaluate your students?

\section{Section II - Training in Assessment}

23. In the English teacher-training seminars/workshops/courses that you have attended so far, did your learn anything about language testing and assessment? If so, what was it?

24. How satisfied were you with these seminars? Did you feel that they appropriately prepared you to assess your students in English?

25. What kind of training in testing and assessment for the English language would you like to have in the future?

26. Is there anything else you would like to add? 